\title{
Agro-Industrial Groundwater Quality Abuja FCT, Nigeria: An Evaluation for Urban and Peri-Urban (UPA) Agricultural Irrigation
}

\author{
Richard Ayuk II Akoachere ${ }^{1^{*}}$ (1), Omogbemi Omoloju Yaya ${ }^{2}$, Areakpoh Thomson Eyong1, \\ Marcelle-Carole Pami Ngassam ${ }^{3}$, Ernest Lytia Molua ${ }^{4}$, Raymond Ndip Nkongho ${ }^{5}$, \\ Elizabeth Orock Ayuk ${ }^{6}$, Tom Tabi Oben ${ }^{5}$
}

\author{
${ }^{1}$ Department of Geology, University of Buea, Buea, Cameroon \\ ${ }^{2}$ National Water Resources Institute, Kaduna, Nigeria \\ ${ }^{3}$ Department of Agricultural and Environmental Engineering, Pan African University/University of Ibadan, Ibadan, Nigeria \\ ${ }^{4}$ Department of Agricultural Economics and Agribusiness, University of Buea, Buea, Cameroon \\ ${ }^{5}$ Department of Agronomy and Applied Molecular Sciences, University of Buea, Buea, Cameroon \\ ${ }^{6}$ Department of Environmental Science, University of Buea, Buea, Cameroon \\ Email: *r.akoachere@ubuea.cm
}

How to cite this paper: Akoachere, R.A., Yaya, O.O., Eyong, A.T., Ngassam, M.P., Molua, E.L., Nkongho, R.N., Ayuk, E.O. and Oben, T.T. (2019) Agro-Industrial Groundwater Quality Abuja FCT, Nigeria: An Evaluation for Urban and Peri-Urban (UPA) Agricultural Irrigation. Open Access Library Journal, 6: e5698.

https://doi.org/10.4236/oalib.1105698

Received: August 12, 2019

Accepted: September 2, 2019

Published: September 5, 2019

Copyright $\odot 2019$ by author(s) and Open Access Library Inc.

This work is licensed under the Creative Commons Attribution International License (CC BY 4.0).

http://creativecommons.org/licenses/by/4.0/

(c) () Open Access

\begin{abstract}
From the declaration made by the African Mayors in Senegal; the Mayors and Municipal Health Officers of the Americas in Columbia; the City Executives of Cities and Local Governments of the World in Spain and in the context of the Millennium Development Goals MDG 1\&7; there is a need for increased food production in urban and peri-urban areas UPA in the world. Sub-Saharan Africa faces more development challenges than any other major region of the world with most of the people living in slums, without access to adequate food, water, or sanitation. UPA contributes to increased food security, nutrition and livelihoods in a combination of ways giving access to consumer markets; less need for packaging, storage and transportation of food; potential agricultural-related jobs and incomes; non-market access to food for poor consumers; availability of fresh, perishable food. In Abuja FCT, 40\% of the populations in UPA are farmers, a reason why the agricultural quality of its groundwater which is used for irrigation begs for our attention. $33 \%$ of the fresh vegetables in the Abuja Federal Capital Territory (FCT) are produced in Abuja UPA. In order to assess groundwater for agro-industrial suitability the following were used: Physicochemical parameters ( $\mathrm{pH}$, Temperature, Electrical Conductivity), Sodium Adsorption Ratio SAR, Permeability Index PI, Magnesium Adsorption Ratio MAR, Percent Sodium \%Na, Kelly's Ratio KR and Residual Sodium Carbonate RSC and the Wilcox diagram. $\mathrm{pH}$ ranged from, 4.8 - 7.9; EC, 13.4 - $1634 \mu \mathrm{S} / \mathrm{cm}$; Temperature, $26^{\circ} \mathrm{C}-36.1^{\circ} \mathrm{C}$ and TDS, 17.42 - $1094.78 \mathrm{mg} / \mathrm{L} . \mathrm{SAR}(0.1>\mathrm{SAR}<2.1)$, Percent Sodium $(7.11>\% \mathrm{Na}<$
\end{abstract}


100), KR $(0>\mathrm{KR}<0.68)$, RSC $(-9.8>\mathrm{RSC}<0.55)$, PI $(13.9>\mathrm{PI}<932.4)$, and MAR $(0>$ MAR $<80.1)$. Comparing these values to WHO and the Nigerian Water Quality guidelines, SAR, $\% \mathrm{Na}, \mathrm{KR}, \mathrm{RSC}$, values are $100 \%$ suitable, while PI, 96.81\% suitable, and MAR 56.46\% unsuitable respectively for irrigational purposes in agriculture. The quality classifications of irrigation water based on the values: Sodium Adsorption Ratio SAR, Wilcox, Kelley Ratio KR, Residual Sodium Carbonate RSC, Permeability Index PI and Percent Sodium $\% \mathrm{Na}$; indicate that groundwater of Abuja FCT is suitable for irrigation purpose on all soil types and that the groundwater will not degrade the soil. However, United States Soil Salinity USSL Index of Abuja FCT groundwater fall in "very low to high salinity" and "low sodium hazard zone" and Magnesium Adsorption Ratio MAR indicates half of the groundwater as "not suitable". Hence the groundwater in Abuja FCT should be used only on soils that are well drained.

\section{Subject Areas}

Agricultural Science, Geology

\section{Keywords}

Irrigational-Water-Quality, Agro-Industrial-Indices,

Urban-Peri-Urban-Agriculture, Abuja FCT

\section{Introduction}

From the declaration made by the African Mayors in Senegal; the Mayors and Municipal Health Officers of the Americas in Columbia; the City Executives of Cities and Local Governments of the World in Spain and in the context of the Millennium Development Goals MDG 1\&7; according to [1] [2], there is a need for increased food production in Urban and Peri-Urban areas (UPA) in the world to feed this influx population.

Sub-Saharan Africa (SSA) faces more development challenges than any other major region of the World. By 2030, it is predicted that almost half (48.3 percent) of SSA's population will be urban. Most of these people will be living in slums, without access to adequate food, water, or sanitation. Urban poverty in SSA has a broader meaning of cumulative deprivation, characterized by squalid living conditions, risk to health and life from poor sanitation, air pollution, natural disasters, and the breakdown of traditional family and community safety-networks as discussed in [3].

UPA contributes to increased food security, nutrition and livelihoods in a combination of ways as discussed in [4] providing:

1) For family self-consumption, contributing to healthy diet/allowing for saving on food expenditures

2) A source of income; sale of surplus or specialized and intensified commercial production systems 
3) The supply of local markets with fresh and micronutrient rich foods at competitive prices

4) A continuum of tree cover: landscape management, use of agroforestry systems and hedgerows.

According to [5] the opportunities include:

1) Access to consumer markets;

2) Less need for packaging, storage and transportation of food;

3) Potential agricultural-related jobs and incomes;

4) Non-market access to food for poor consumers;

5) Availability of fresh, perishable food;

6) Proximity to services, including waste treatment facilities;

7) Wastes and by-products recycling and re-use possibilities.

The risks as stated by [6] include:

1) Environmental and health risks from inappropriate agricultural and aquaculture practices;

2) Increased competition for land, water, energy, and labor.

In Abuja FCT, $40 \%$ of the population in the urban and peri-urban area UPA are farmers as discussed in [2], a reason why the agricultural quality of its groundwater begs for our attention. 33\% of the fresh vegetables in the Abuja Federal Capital Territory (FCT) are produced in Abuja UPA. Irrigation waters derived from springs, diverted from streams, or pumped from wells, contain appreciable quantities of chemical substances in solution that may reduce crop yield and deteriorate soil fertility. In addition to the dissolved salts, which have been the major problem for centuries, irrigation water always carries substances derived from its natural environment or from the waste products of man's activities (domestic and industrial effluents). Small-scale irrigation continues to cushion the food security gap in sub-Saharan Africa. Irrigation is largely governed by water availability, soil type and crop water requirements, among other factors.

The study aims to evaluate the quality of groundwater for irrigation purposes in Abuja FCT. The water quality parameters used are: $\mathrm{pH}$, electrical conductivity (EC), Total Dissolved Solids (TDS), sodium adsorption ratio (SAR), sodium percent $(\mathrm{Na} \%)$, magnesium adsorption ratio (MAR), Kelley's ratio (KR), Residual Sodium Carbonate (RSC), chloride $(\mathrm{Cl})$ and the Permeability Index (PI).

The Abuja (FCT) bounded between $8^{\circ} 45-9^{\circ} 40^{\prime} \mathrm{N}$ and $6^{\circ} 50^{\prime} \mathrm{E}-8^{\circ} 55^{\prime} \mathrm{E}$ and covering an area of about $8000 \mathrm{~km}^{2}$ was conceived with adequate allocation of resources, to be a model city of urbanization in sub-Saharan Africa.

Plagued by challenges of water quantity and most times even when there is adequate quantity the water is of dubious quality due to a multitude of reasons least which stems from handling.

\subsection{Location}

The study area lies between $8.92 \mathrm{~N}-9.20 \mathrm{~N}$ and 7.25E - 7.60E in Abuja Federal Capital Territory (FCT) as seen in Figure 1. It is bounded in the east by Nasarawa State, north by Kaduna State, west by Niger State and south by Kogi State. 


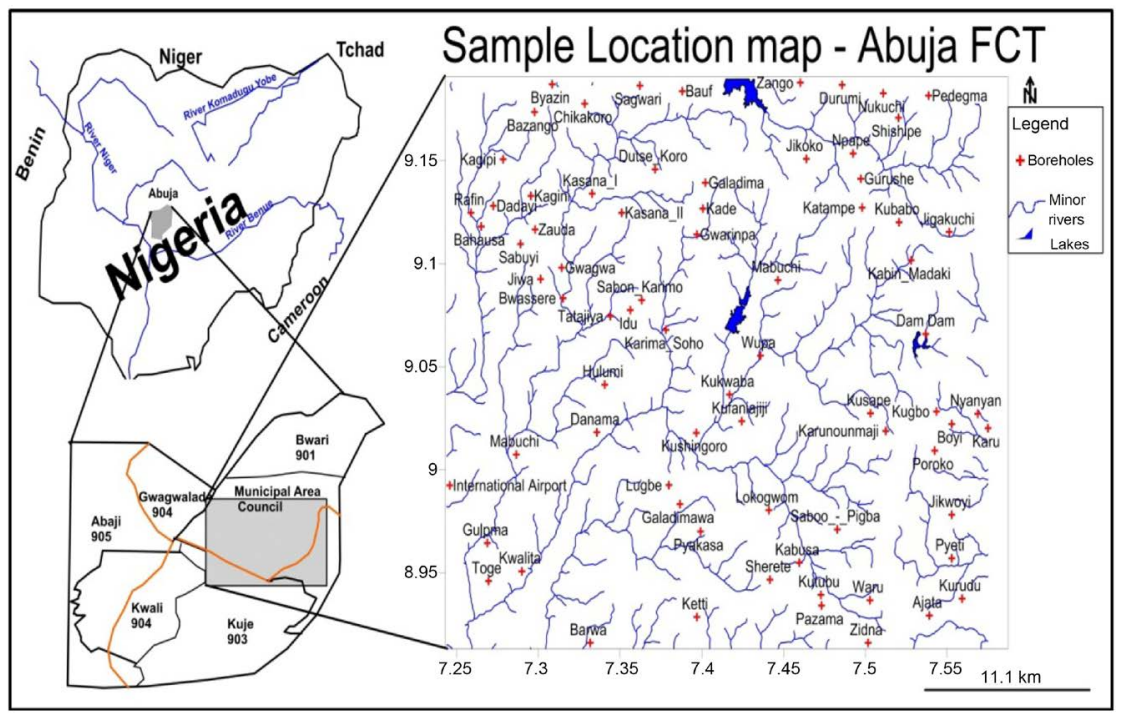

Figure 1. Location of the study area showing field tested and sampling points.

\subsection{Physiology}

The topography of Abuja is undulating with hills and an inselberg that rise northwestwards to a maximum of $1060 \mathrm{~m}$ above sea level. There are extensive plains found between hills in the study area. The Zuma rock stands out clearly on its own as the most conspicuous inselberg at the boundary of the Abuja with Niger State. The lowest elevations are in the southwestern flood plains of the River Gurara, about $76 \mathrm{~m}$ above sea level.

The rivers rise from the hills in the northeast and flow to the southwest. The area is drained by many rivers in and around Abuja including Rivers Gwagwalada and Usmanu while Rivers Wupa, Wosika and other smaller seasonal southerly-flowing streams form the tributaries and drain the study area. The drainage pattern generally varies from trellis to dendritic. The major rivers join at Nyimbo village to form a tributary of River Niger in the south. These rivers depend on rainfall for their recharge. As such, their stages are high in rainy season and decrease drastically during the dry season.

\subsection{Climate}

The area has its highest temperature of about $36^{\circ} \mathrm{C}$ during the dry season, November to March. During the rainy season April to October, the temperature drops to a maximum of $24^{\circ} \mathrm{C}$ as discussed in [7]. The annual rainfall ranges from $1100 \mathrm{~mm}$ to $1600 \mathrm{~mm}$ as discussed in [8]. Two types of vegetation occur; the forest predominantly of woody plants thorn bushes and trees in which grasses are virtually absent comprise mainly of secondary forest, which is continuously degraded for subsistence farming and habitation and the savanna herbs and shrubs, the study area being in Guinean Savanna Vegetation Zone of Nigeria.

\subsection{Geology}

The geology of Abuja FCT has been described by many workers, including [7] 
[9] [10]. It is underlain by Precambrian rocks of the Nigerian Basement Complex which cover about $85 \%$ of the land surface and cretaceous sedimentary rocks belonging to the Bida Basin which cover the remaining $15 \%$.

\section{Materials and Methods}

\subsection{Field Mapping, Measurements and Sampling}

Ninety-four (94) groundwater samples were collected from productive boreholes in the study area after a geological traverse field mapping exercise and borehole water field testing for physico-chemical parameters, following standard sampling protocols as discussed in [11] as seen in Figure 2. Boreholes for tests and measurements were selected based on three criteria:

1) Availability of data

2) Being functional and in use

3) Not deeper than our water level indicator $50 \mathrm{~m}$ and Sonar bottom sounder $61 \mathrm{~m}$.

Groundwater samples were analyzed as discussed in [12] at Activation Laboratory (Actlabs), Canada. The following groundwater and borehole physical parameters were measured in-situ in the field using calibrated field instruments; Hanna HI 98127 (pH), HI 98304 (EC), HI 96304 (TDS), HI 9147 (DO), Groundwater temperature and electrical conductivity in boreholes was profiled real-time using Solinstlevelogger for Static Water Level measurements as shown Table 1. Geolocation and elevation measurements of boreholes were done using a Global Positioning System (GPS) Garmin 60CSx.

In order to assess groundwater for agro-industrial suitability the following parameters were used; sodium adsorption ratio SAR, permeability index PI,

Table 1. Field equipment, specifications and functions.

\begin{tabular}{|c|c|c|}
\hline Equipment/Softwares & Specifications & Functions \\
\hline Bike & Commercial bikes (Achaba) & To transport fieldworkers to wells \\
\hline GPS & Garmin GPSMAP 60CSx & To measure longitude, latitude and elevation of wells \\
\hline EC Meter & Hanna HI 98304/HI98303 & To measure Electrical Conductivity of water. \\
\hline pH Meter & Hanna HI 98127/HI98107 & To measure $\mathrm{pH}$ of water. \\
\hline Water level indicator & Solinst Model 102M & To indicate static water levels of water in wells \\
\hline Measuring Tape & Weighted measuring tape & Measurement of well diameter and depth. \\
\hline Digital Thermometer & Extech $39240\left(-50^{\circ} \mathrm{C}\right.$ to $\left.200^{\circ} \mathrm{C}\right)$ & To measure temperature of water \\
\hline Total Dissolved Solid meter & Hanna HI 96301 with ATC & To measure Total dissolved solids in water \\
\hline Water sampler & Gallenkampf $1000 \mathrm{ml}$ & To collect well water sample from well \\
\hline Sample bottles & Polystyrene $500 \mathrm{ml}$ & To hold sample for onward transmission to laboratory \\
\hline Global Mapper & Version 15 & GIS Geolocation of wells \\
\hline Surfer Software & Version 12 & GIS plotting contours for spatial distribution \\
\hline AqQA/Aquachem & Version 1.5 & For the analysis/interpretation of water chemistry \\
\hline
\end{tabular}




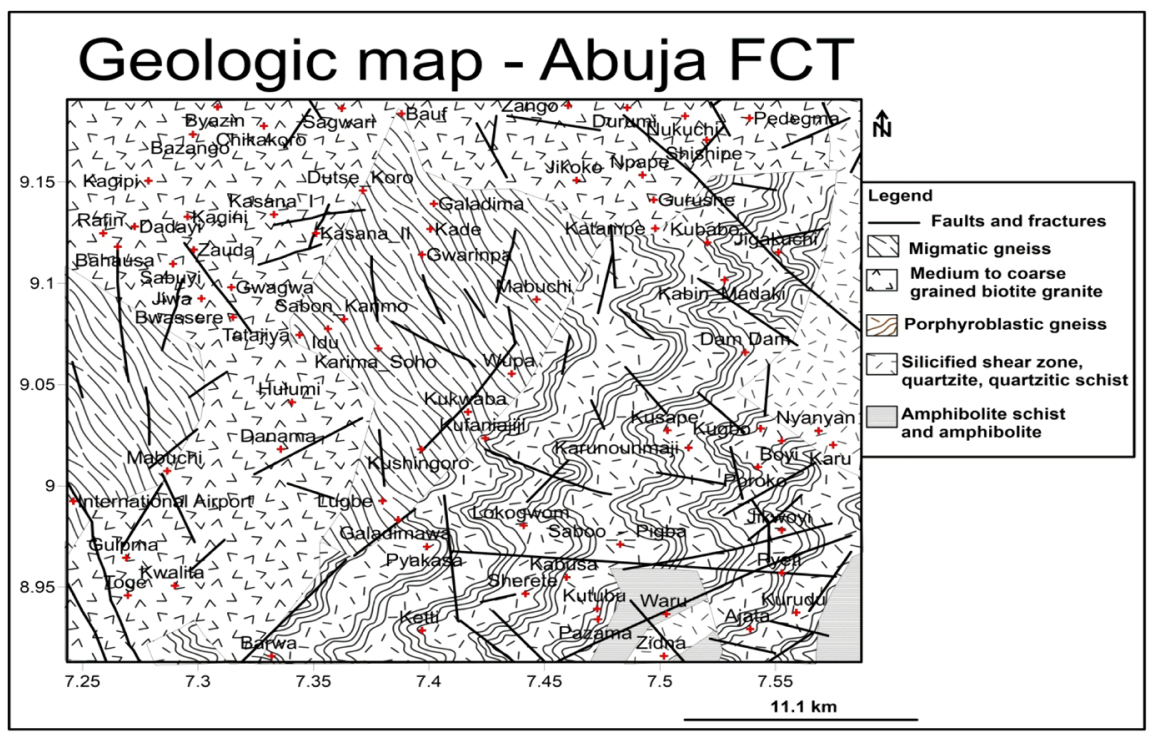

Figure 2. Geologic map of the study area.

Magnesium adsorption ratio MAR, percent sodium \%Na, Kelly's ratio KR and Residual sodium carbonate RSC and Wilcox diagram as shown in Table 2.

Data from the geological traverse field mapping, field tests, field measurements and laboratory analysis were placed on MS Excel spreadsheets, and then mounted unto various GIS and software platforms, Rockworks14, Surfer V12, Grapher, AQqa and Enviroinsite where they were vigorously queried as shown in Table 1.

\section{Results and Discussion}

\subsection{Physicochemical Parameters}

The measured physicochemical parameters of groundwater in Abuja FCT: Temperature, $\mathrm{pH}, \mathrm{EC}$ and TDS for 94 boreholes were evaluated as shown in Table 3 .

\subsection{Digital Elevation Model}

Abuja has an undulating relief of hills and valleys. The land surface is covered by top soil in most areas as seen in Figure 3. The topography of the Abuja is varied with the lowest elevations in the extreme southwest at the floodplains of the River Gurara, about $76 \mathrm{~m}$ above sea level and it rises irregularly northwestwards to a height of $760 \mathrm{~m}$ above sea level. There are numerous hills that occur in the area but the Zuma rock stands out clearly on its own as the most conspicuous Inselberg at the boundary of the Abuja with Niger State.

\subsection{Water Level Fluctuations}

Groundwater levels range from $3-12.5$ as seen in Figure 4. Relatively higher water levels are at Kwalita, Galadimawa, Wupa, Pigba, Kurundu and Pyeti whereas lower values are at Pedegma, Nukuchi, Durumi and Zangl. These low depths to 
Table 2. Indices used in the calculation of irrigation water quality.

\begin{tabular}{ccc}
\hline & Formula & Reference \\
\hline Percentage Sodium & $\% \mathrm{Na}=\frac{\mathrm{Na}^{+}+\mathrm{K}^{+}}{\mathrm{Na}^{+}+\mathrm{K}^{\mathrm{s}}+\mathrm{Ca}^{2+}+\mathrm{Mg}^{2+}} \times 100$ & \\
Kelly's Ratio & $\mathrm{KR}=\frac{\mathrm{Na}^{+}}{\mathrm{Ca}^{2+}+\mathrm{Mg}^{2+}}$ & \\
Magnesium Adsorption Ratio & $\mathrm{MAR}=\left(\frac{\mathrm{Mg}^{2+}}{\mathrm{Mg}^{2+}+\mathrm{Ca}^{2+}}\right) \times 100$ & \\
Residual Sodium Carbonate & $\mathrm{RSC}=\left(\mathrm{CO}_{3}+\mathrm{HCO}_{3}-(\mathrm{Ca}+\mathrm{Mg})\right)$ & \\
Sodium Adsorption Ratio & $\mathrm{SAR}=\frac{\mathrm{Na}}{\sqrt{\frac{\mathrm{Ca}+\mathrm{Mg}}{2}}}$ \\
Permeability Index & $\mathrm{PI}=\frac{((\mathrm{Na}+\mathrm{K})+\sqrt{\mathrm{HCO}}) * 100}{\mathrm{Ca}+\mathrm{Mg}+\mathrm{Na}+\mathrm{K}}$
\end{tabular}

Table 3. Basic statistics of the physicochemical parameters found in Abuja groundwater, min, max, mean and standard deviation.

\begin{tabular}{ccccc}
\hline Parameter & Min & Max & Mean & Std \\
\hline $\mathrm{T}\left({ }^{\circ} \mathrm{C}\right)$ & 26.0 & 36.1 & 31.35 & 2.19 \\
$\mathrm{PH}$ & 4.8 & 7.9 & 6.04 & 0.67 \\
$\mathrm{EC}(\mathrm{mS} / \mathrm{cm})$ & 13.4 & 1634 & 265.21 & 281.26 \\
$\mathrm{TDS}(\mathrm{mg} / \mathrm{L})$ & 17.42 & 1094.78 & 178.88 & 187.74 \\
\hline
\end{tabular}

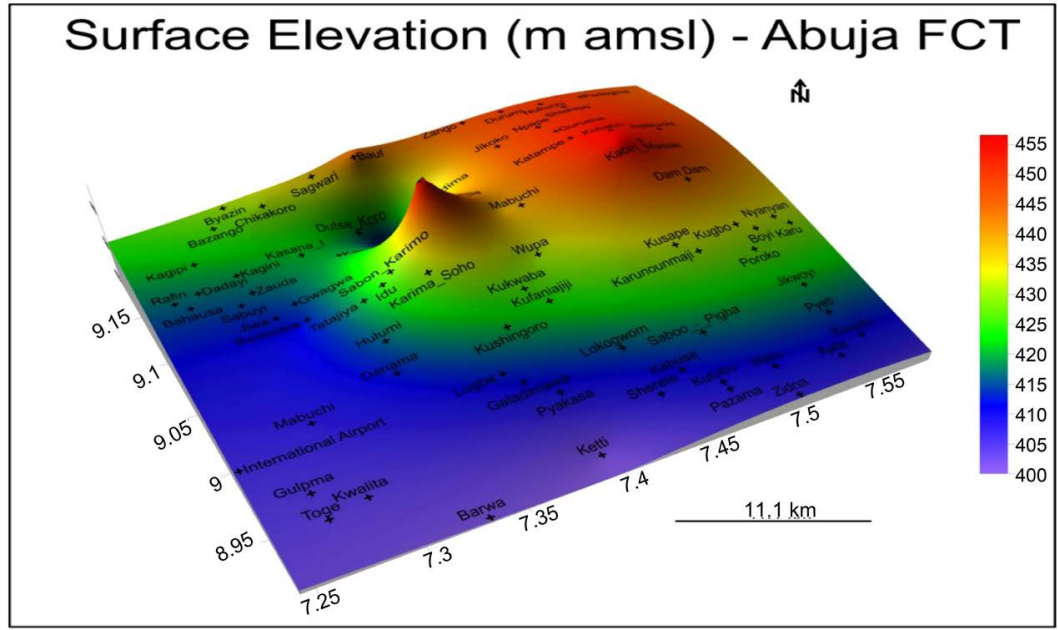

Figure 3. Spatial variation of elevation above mean sea level.

water are prone to pollution if the wells are not appropriately constructed and protected.

\subsection{Temperature}

The temperature of the groundwater in Abuja is relatively high; range from 26.0

- 36.1 as seen in Figure 5. The temperature variation was similar in the different 


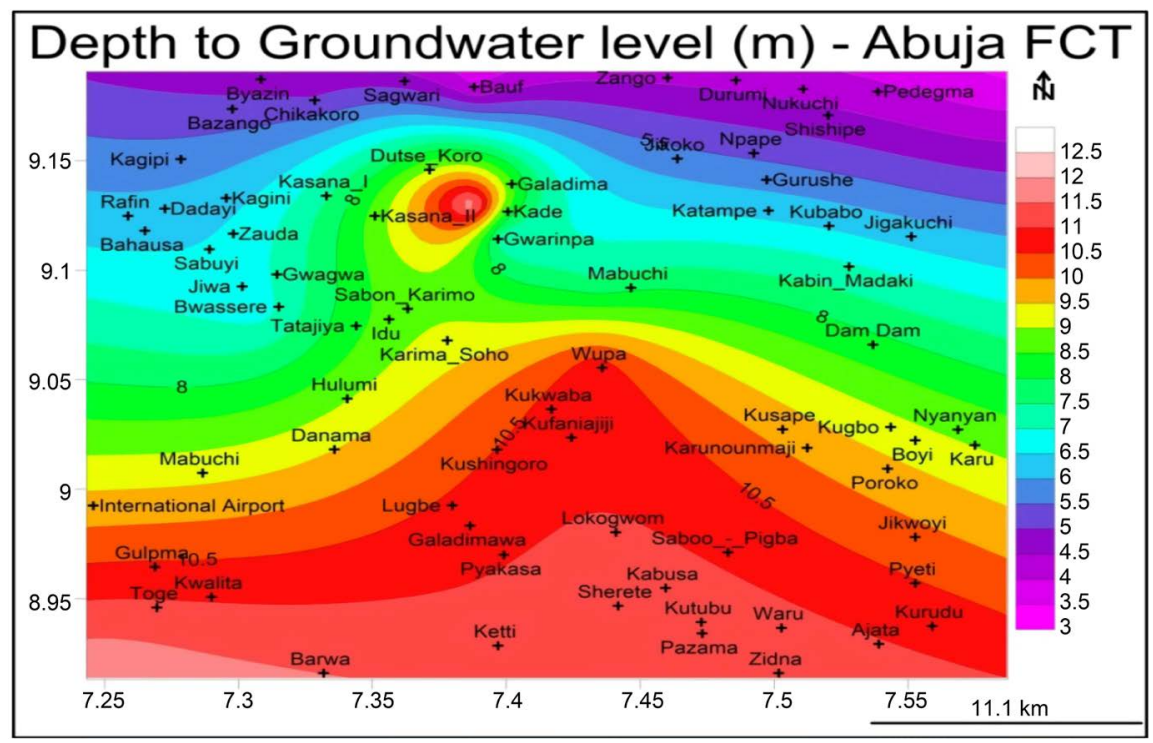

Figure 4. Depth to static water levels of Abuja groundwater. High values are at Kwalita, Galadimawa, Wupa, Pigba, Kurundu and Pyeti whereas low values are at Pedegma, Nukuchi, Durumi and Zango.

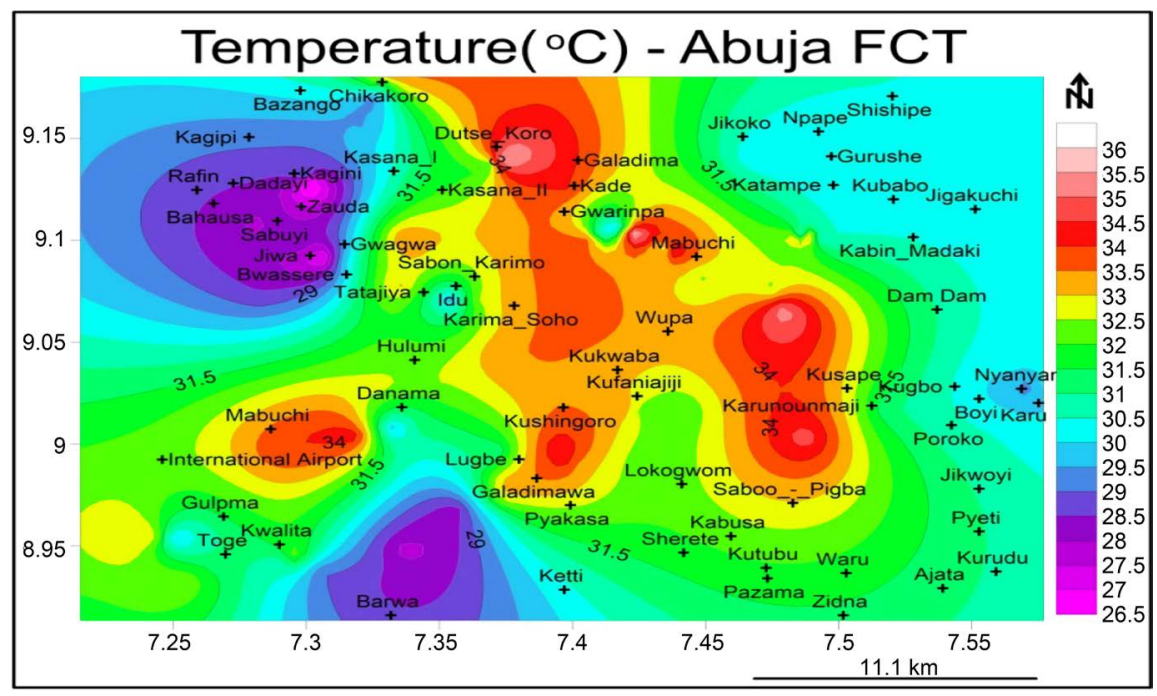

Figure 5. Spatial variation of temperature in Abuja; Note high temperature values around Koro, Kade, Galadima, Mabuchi, Kushingoro and Karunounmaji whereas low temperature values are at Kgjini, Jiwa, Dadayi, Sabuyi.

areas, suggesting a single aquifer since groundwater in the same aquifers have similar parameter values and temperature is one of them.

\section{5. $\mathrm{pH}$}

$\mathrm{pH}$ is the concentration of hydrogen ions $\left(\mathrm{H}^{+}\right)$and hydroxyl ions $\left(\mathrm{OH}^{-}\right)$in water. Groundwater redox potential depends on the number of cations and anions in solution since $\mathrm{pH}$ determines the ions dissolved or precipitated in the groundwater. As the $\mathrm{pH}$ of the irrigation water increases above 8.2, the potential for sodium dissolution in the soil increases. The generally accepted $\mathrm{pH}$ for irri- 
gation water is between 5.5 and 7.5 as discussed in [19]. Good irrigation water tends to be alkaline, commonly in the range of $\mathrm{pH} 7.2$ to 8.5 . The $\mathrm{pH}$ of groundwater in Abuja FCT, range from 4.8 - 7.9 as seen in Figure 6. A total of 71 of groundwater $(75.5 \%)$ in the study area had $\mathrm{pH}$ within the acceptable limits for irrigation whereas 23 of the samples (24.5\%) are unsuitable for irrigation.

\subsection{Electrical Conductivity}

The primary effect of high EC water on crop productivity is the inability of the plant to compete for ions in the soil solution for water due to negative osmotic pressure gradient which causes physiological drought though even when the soil is wet. Based on EC values, irrigation water is classified into different classes. EC values in $\mu \mathrm{S} / \mathrm{cm}$ between 0 - 100, excellent class, EC 101 - 250 very good, EC 251 - 750 good, EC 751 - 2250 doubtful and greater than 2250 unsuitable respectively as shown in Table 4. A total of 70 samples (72.34\%) have EC less than 250 which indicate very good suitability of water for irrigation whereas, 24 samples $(27.66 \%)$ have EC greater than 250.

\subsection{Total Dissolved Solids}

During irrigation, the dissolved salts are applied with the water and remain behind in the soil as water evaporates or is used by the crop; this salts accumulate in the crop root zone to concentrations that cause loss in yield, since the crop is no longer able to extract sufficient water from the salty soil solution, resulting in a water stress. For irrigation purposes, the quality of water depends on the quantity of dissolved salts. Salinity problems occur if salt accumulates in the root zone, which may significantly affect the quantity of crop production as discussed in [20].

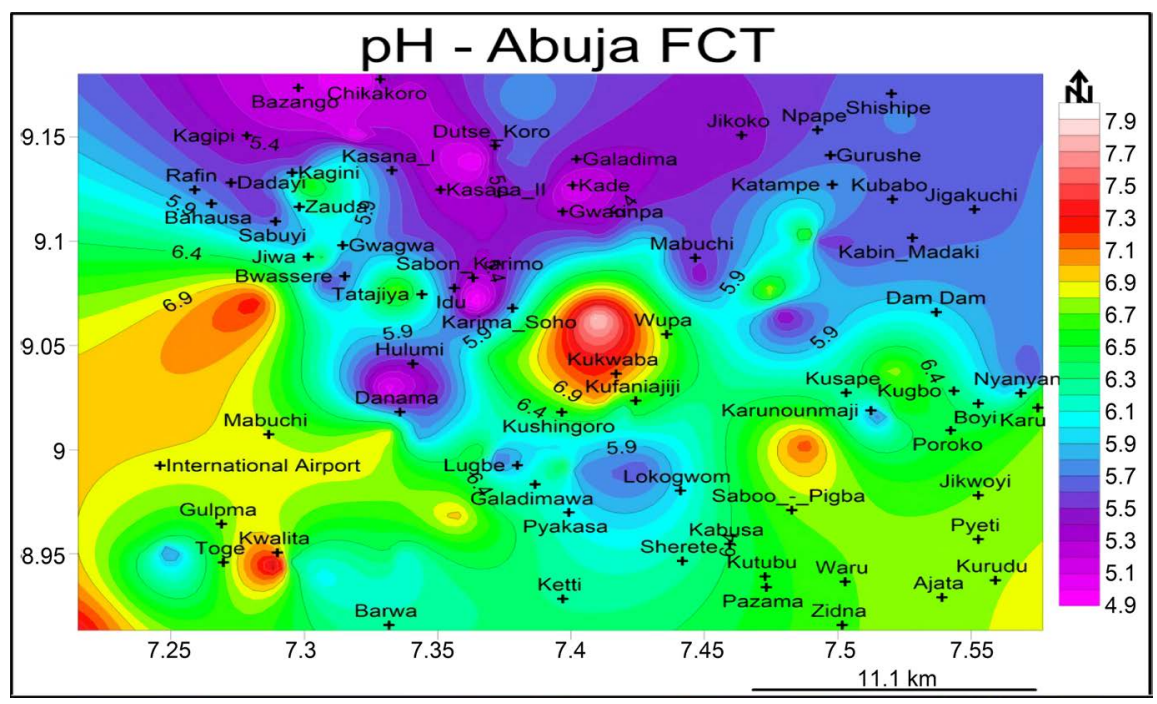

Figure 6. Spatial variation of $\mathrm{pH}$ in Abuja; Note high $\mathrm{pH}$ values around Kwalita, Kukwaba, Kufaniajiji whereas low pH values are at Danama, Bazango, Chikakoro, Dutse, Kade, and Galadima. 
Table 4. Water quality classifications of: TDS, EC, $\mathrm{pH}$, and $\mathrm{Cl}$ values.

\begin{tabular}{|c|c|c|c|c|}
\hline Class & Values & Quality & No & $\%$ \\
\hline \multicolumn{3}{|c|}{$\mathrm{Cl}^{-}$classification } & \multicolumn{2}{|c|}{ [22] } \\
\hline 1 & $<70$ & Safe for most plants & 73 & 77.7 \\
\hline 2 & $70-140$ & Sensitive plants show injury & 21 & 22.3 \\
\hline \multicolumn{3}{|c|}{ TDS classification } & \multicolumn{2}{|c|}{ [22] } \\
\hline 1 & $<1000$ & Best quality water & 93 & 98.9 \\
\hline 2 & $1000-3000$ & Water involving hazard & 1 & 1.1 \\
\hline \multicolumn{3}{|c|}{ EC classification } & \multicolumn{2}{|c|}{$[16]$} \\
\hline 1 & $0-100$ & Excellent & 16 & 17.02 \\
\hline 2 & $101-250$ & Very Good & 52 & 55.32 \\
\hline 3 & $251-750$ & Good & 19 & 20.21 \\
\hline \multicolumn{5}{|c|}{$\mathrm{pH}$ classification } \\
\hline 1 & $<5.5$ & Unaccepted & 71 & 75.53 \\
\hline 2 & $5.5-7.5$ & accepted & 21 & 22.34 \\
\hline 3 & $>7.5$ & unaccepted & 2 & 2.12 \\
\hline
\end{tabular}

Water with TDS less than $1000 \mathrm{mg} / \mathrm{L}$ is considered good and that which is greater than $2000 \mathrm{mg} / \mathrm{L}$ is unsuitable for agricultural purposes as presented in Table 4. Water with TDS $>2000 \mathrm{mg} / \mathrm{L}$ has severe risk on irrigational waters. In Abuja FCT, 93 groundwater samples (98.9\%) have TDS values $<1000$ which is the best value for irrigational water suitability. One groundwater sample (1.1\%) has a value of $1094 \mathrm{mg} / \mathrm{L}$. The values range from $17.42-1094.78 \mathrm{mg} / \mathrm{L}$ with the highest value observed at Kuru, Gwagwa, Kurundu, and Barwa whereas low values are at Nyana, Dam Dam, Jikoko, Galadima, Kade, Mabuchi, and Jikoko as seen in Figure 7.

\subsection{Chloride}

Chloride is considered as the most common toxic ion in irrigation water. Since, it is not adsorbed by the soil colloids; therefore, it travels easily with soil water, is absorbed by the crop, moves into the transpiration stream, and accumulates in the leaves. Once the chloride concentration in the leaves exceeds the tolerance of the crop, injury symptoms develop, such as leaf burn or drying of leaf tissue as discussed in [22]. In groundwater the origin of chloride may be from diverse sources such as weathering, leaching of sedimentary rocks and soils, intrusion of saltwater, windblown salt in precipitation, domestic and industrial waste discharges, municipal effluents, as discussed in [23] [24]. In groundwater the concentration of chloride ion up to $70 \mathrm{mg} / \mathrm{L}$ is considered safe and causes severe problem in the crops at concentration $>70 \mathrm{mg} /$ Las discussed in [25]. Chloride is an essential micronutrient and the plant should be productive if chloride concentration is less than $70 \mathrm{mg} / \mathrm{L}$ in irrigation water as discussed in [26]. In the 


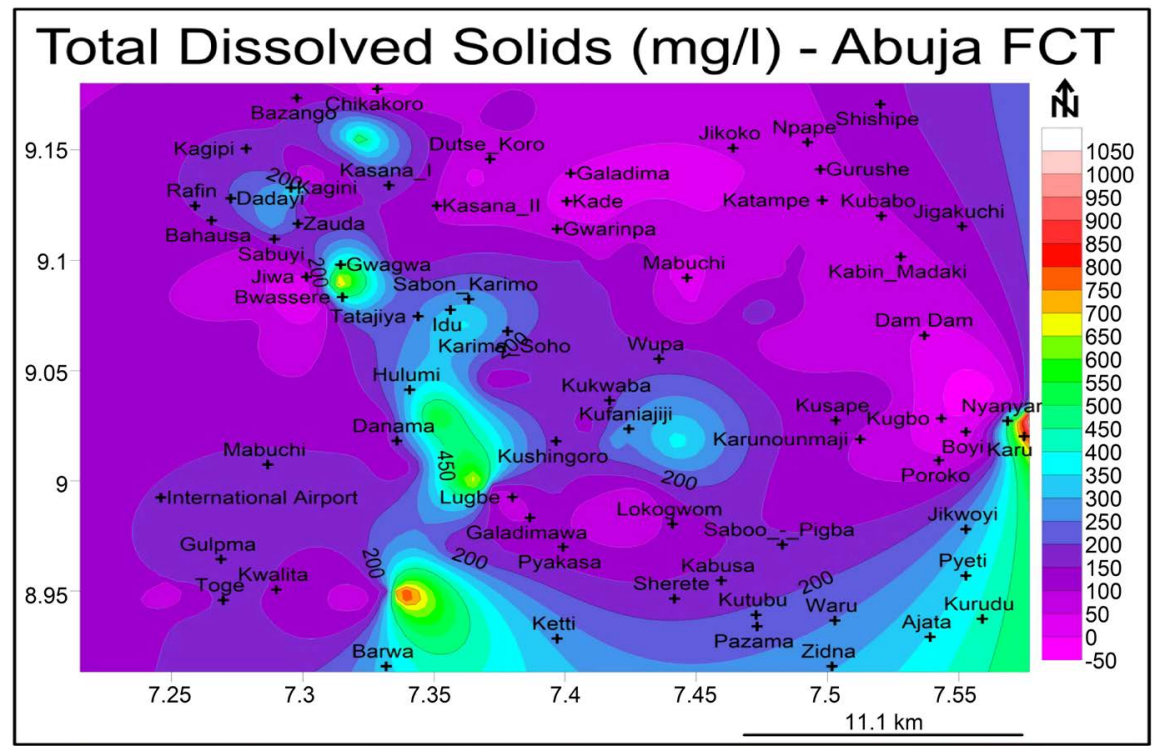

Figure 7. Spatial variation of total dissolved solids (mg/L) in Abuja; TDS is maximum at Kuru, Gwagwa, Kurundu, and Barwa whereas low values are at Nyana, Dam Dam, Jikoko, Galadima, Kade, Mabuchi, and Jikoko.

present study, $77.7 \%$ of the water samples have $\mathrm{Cl}^{-}$concentration $<70 \mathrm{mg} / \mathrm{L}$ which is the required concentration for irrigation waters as shown in Table 4.

All other inorganic elements fall below the WHO guidelines.

\subsection{Sodium Percent and Wilcox Diagram}

For irrigation purpose, the percentage of sodium is important, because sodium reacts with soil to reduce permeability as discussed in [27]. The use of high percentage sodium water for irrigation purpose stunts the plant growth. Sodium reacts with soil to reduce its permeability. Usually little or only minor problems occur when sodium percentage values are less than $15 \%$. When sodium percentage $>15 \%$, reduced permeability will occur. In Abuja FCT Sodium percent values range from 7.11 - 100. Sodium along with carbonate forms alkaline soil; while sodium with chloride forms saline soil; both of these are not suitable for the growth of plants as discussed in [28]. The quality classifications of irrigation water based on the values of sodium percentage as proposed by as discussed in [13] suggest that the groundwater of the study area is excellent to good, good to permissible, and permissible to doubtful as seen in Figure 8 indicating the water is suitable for irrigation.

\subsection{Sodium Adsorption Ratio and USSL Diagram}

Sodium adsorption ratio is an irrigation water quality parameter used in the management of sodium-affected soils. It is an indicator of the suitability of water for use in agricultural irrigation, as determined from the concentrations of the main alkaline and earth alkaline cations present in the water as stated by as discussed in [29]. SAR allows assessment of the state of flocculation or of dispersion 


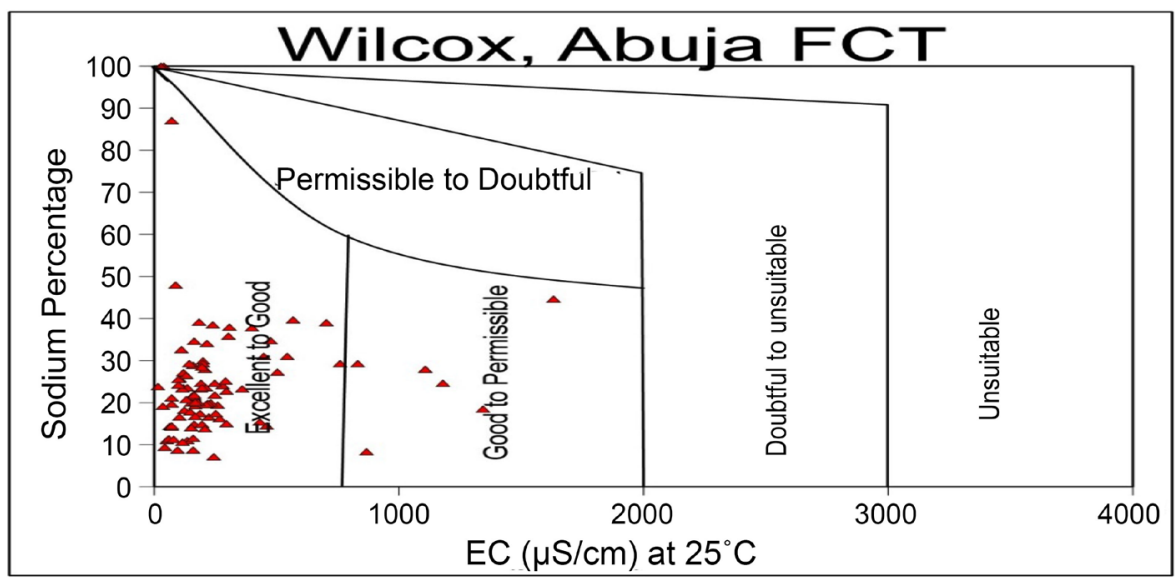

Figure 8. Wilcox diagram showing groundwater suitability for irrigation water samples plotting in excellent to good, good to permissible, and permissible to doubtful field.

of clay aggregates in a soil. Sodium and potassium ions facilitate the dispersion of clay particles while calcium and magnesium promote their flocculation. SAR values range from $0.1-2.1$ as seen in Figure 9. Based on SAR values, irrigation water is classified into different classes which indicates that SAR value between 0 - 10, that is, low sodium water poses almost no risk of exchangeable sodium, medium sodium water having SAR 10 - 18 can show considerable hazard, while on the contrary, high and very-high sodium water with SAR 18 - 26 and greater than 26 , respectively are regarded as unfavorable as they can lead to detrimental levels of exchangeable sodium in soils as discussed in [21] [22]. All the 94 groundwater samples have SAR values $<10$ which is indicative that the groundwater can be used for irrigation on almost all soil types with little danger of the development of harmful levels of exchangeable sodium as seen in Figure 10. Excess sodium in waters produces the undesirable effects of changing soil properties and reducing soil permeability.

\subsection{Permeability Index}

Soil permeability is affected by long term use of irrigation water as it is influenced by total dissolved salts, sodium content and bicarbonate content. Permeability index is a crucial parameter for assessing the suitability of irrigation water. High permeability index would facilitate extensive contamination of groundwater as discussed in [30]. The PI values range 13.97 - 932.43 as seen in Figure 11. In accordance with PI, as discussed in [18] attempted the classification of permeability Index as Class I, II and III. Class I and II water are categorized as good for irrigation with $75 \%$ or more of maximum permeability. Class III water is unsuitable with $25 \%$ of maximum permeability. The groundwater samples of the study area fall in class-I and II as per Doneen chart as seen in Figure 12 and shown in Table 5, the groundwater samples of the study area are of good quality for irrigation. The increased percentage of groundwater samples under class-I is due to dilution subsequent lower values of permeability index. 


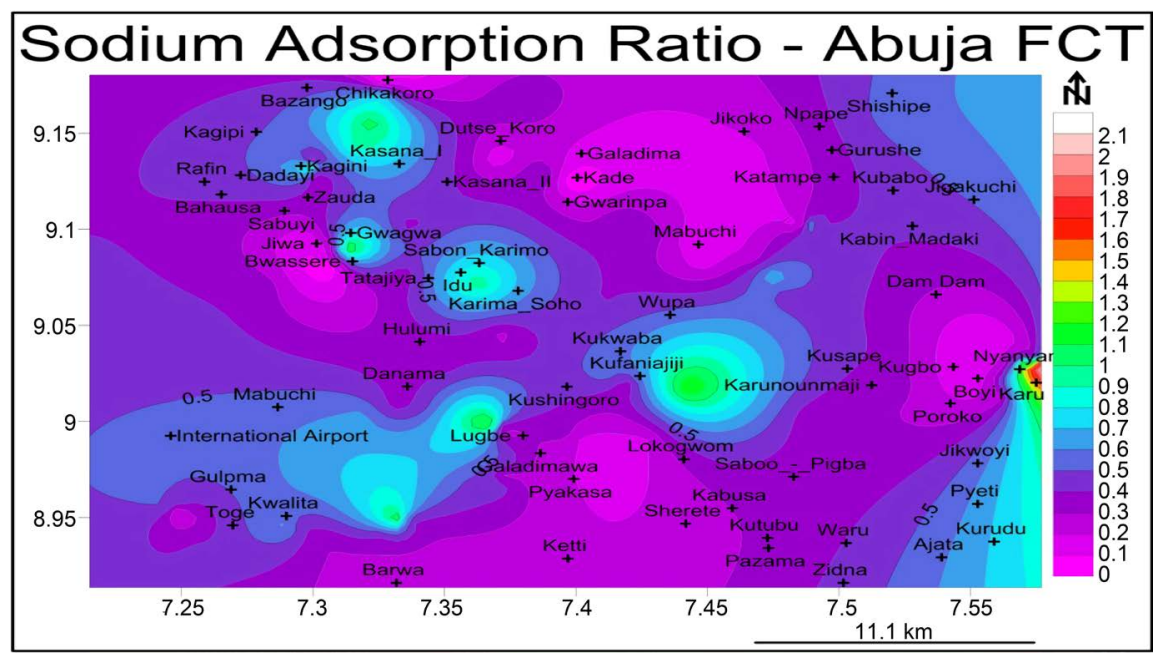

Figure 9. Spatial variation of dug well water sodium adsorption ratio SAR; Note increase in SAR values around Kuru and Nyanya the SAR values decreases at Kade, Ketti, Barwa, Galadima, Jiwa, Poroko, and Sabuyi.

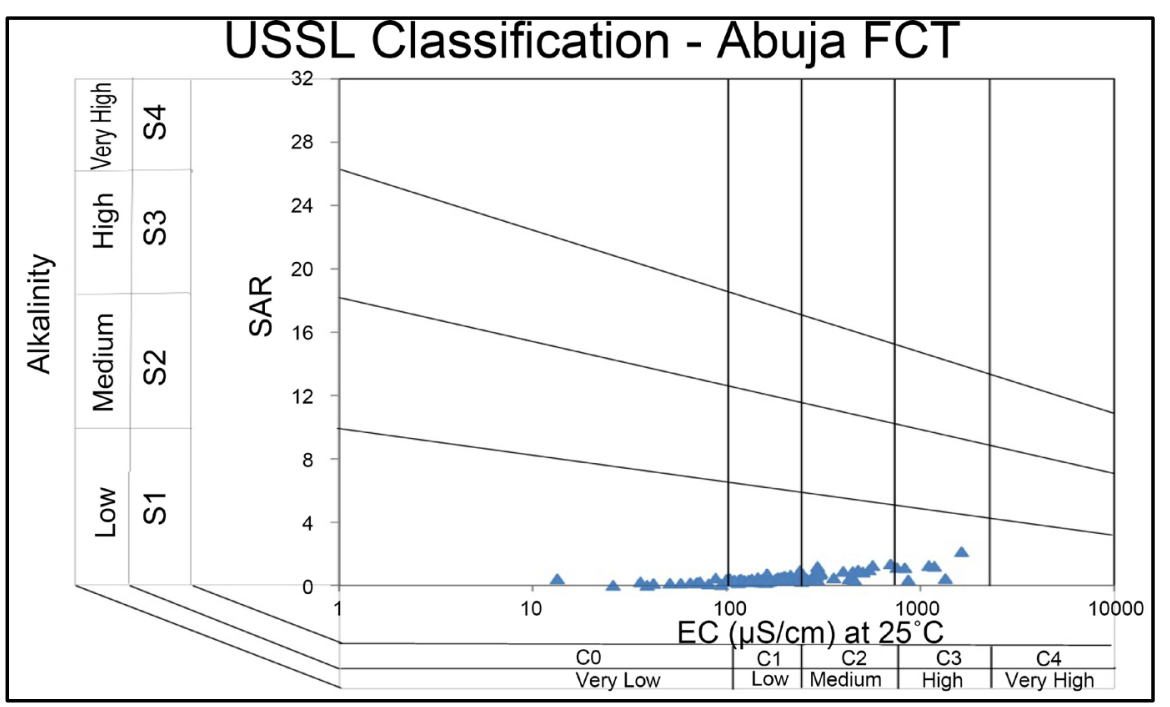

Figure 10. Residual salinity hazard classification; The $\mathrm{S}_{1} \mathrm{C}_{0}, \mathrm{~S}_{1} \mathrm{C}_{1}, \mathrm{~S}_{1} \mathrm{C}_{2}$ and $\mathrm{S}_{1} \mathrm{C}_{3}$ make up the excellent, very good, good, and doubtful classes respectively. 16 samples $17.02 \%$ plotted in the excellent class, 52 samples $55.32 \%$ plotted in the very good class, 19 samples $20.21 \%$ potted in the good class and 7 samples $7.45 \%$ potted in the doubtful class.

Table 5. Water quality classifications of: SAR, PI, MAR, RSC and KR indices.

\begin{tabular}{|c|c|c|c|c|}
\hline Class & Values & Quality & No & $\%$ \\
\hline \multicolumn{3}{|c|}{ SAR classification } & \multicolumn{2}{|c|}{ [21] [22] } \\
\hline S1 & $<10$ & Excellent & 94 & 100 \\
\hline \multicolumn{3}{|c|}{ PI classification } & \multicolumn{2}{|c|}{ [18] } \\
\hline I & $>75$ & Excellent & 91 & 96.81 \\
\hline II & $50-75$ & Good & 3 & 3.19 \\
\hline \multicolumn{3}{|c|}{ MAR classification } & \multicolumn{2}{|c|}{$[15]$} \\
\hline 1 & $<50$ & Suitable & 41 & 43.6 \\
\hline
\end{tabular}




\section{Continued}

\begin{tabular}{|c|c|c|c|c|}
\hline 2 & $>50$ & Unsuitable & 53 & 56.4 \\
\hline \multicolumn{3}{|c|}{ RSC classification } & \multicolumn{2}{|c|}{ [16] [17] } \\
\hline 1 & $<1.25$ & Good & 94 & 100 \\
\hline \multicolumn{3}{|c|}{ KR classification } & \multicolumn{2}{|c|}{ [14] } \\
\hline 1 & $<1$ & Suitable & 94 & 100 \\
\hline
\end{tabular}

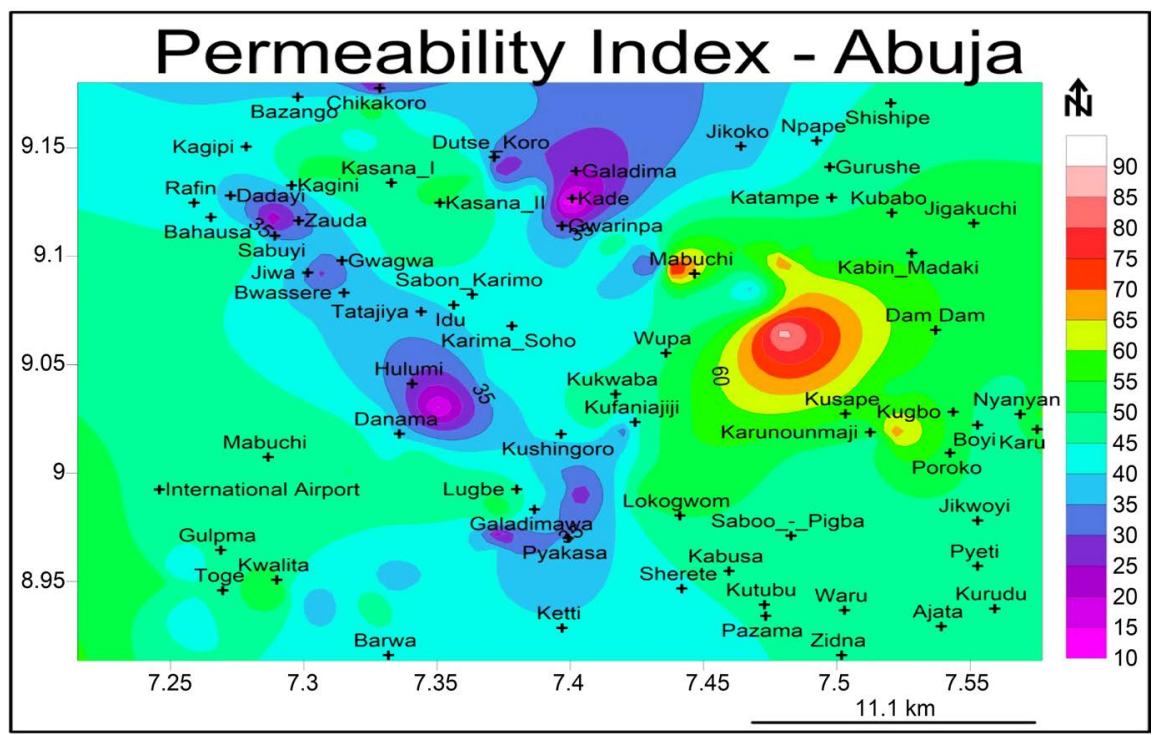

Figure 11. Spatial variation of permeability index in Abuja; Permeability index is highest at Mabuchi, Kusape and lowest at Kade and Galadima.

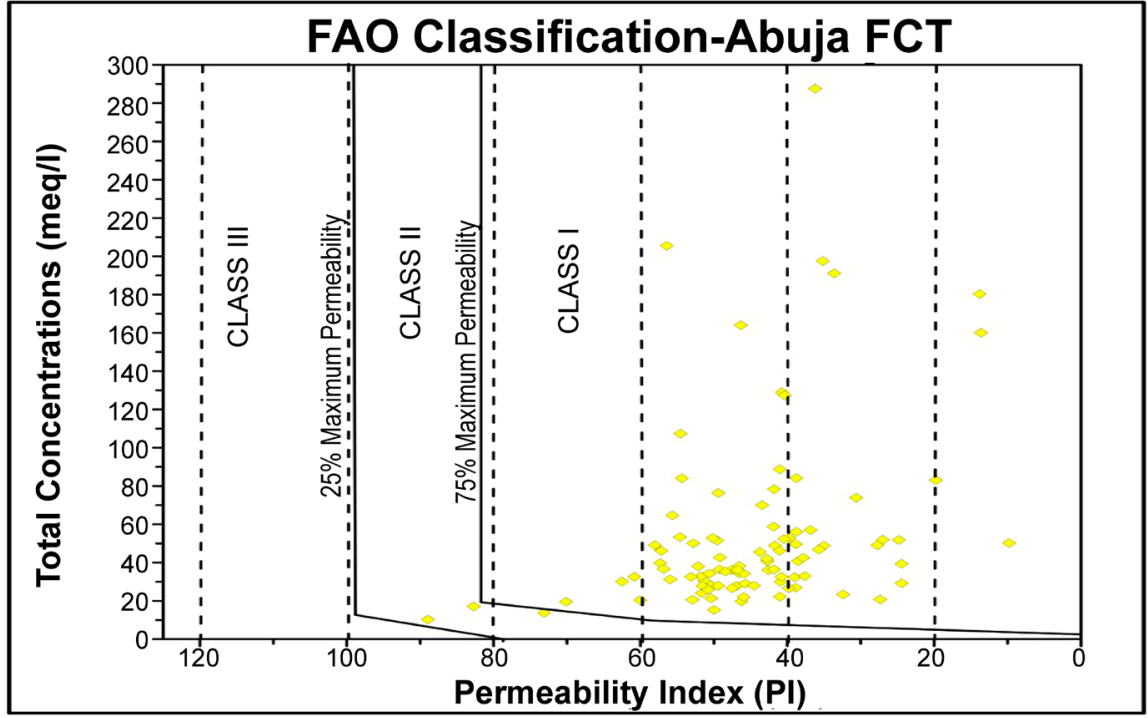

Figure 12. FAO classification of groundwater for irrigation with all the samples plot in class I and class II field indicating that the water is suitable for irrigation.

\subsection{Magnesium Adsorption Ratio}

Excess of magnesium in the soil easily affects the crop yield as soils become more 
alkaline. Magnesium adsorption ratio values range from 0 - 80.1 as seen in Figure 13. Magnesium adsorption ratio less than $50 \%$ it is considered as suitable for irrigation purpose. In the study area, $43.6 \%$ of the samples are suitable for irrigation whereas $56.4 \%$ of the samples are not suitable for irrigation. Samples with high magnesium ratio may be due to the passage of surface water and subsurface water through granitic rock formations in Abuja FCT as discussed in [28]. As discussed in [31] reported $89 \%$ of samples as good for irrigation whereas 11 percent samples are unsuitable in their study.

\subsection{Residual Sodium Carbonate}

RSC values were calculated to determine the hazardous effect of $\mathrm{CO}_{3}$ and $\mathrm{HCO}_{3}$ of groundwater in Abuja FCT on the water quality for agricultural purpose. If the evaporation of water does not occur from the soil and the solution stays at equilibrium or unsaturated with respect to calcite, bicarbonate will pass through the soil. A negative RSC is the best condition because the total concentration of carbonate and bicarbonate is lower than the concentration of calcium and magnesium combined which implies that there is no residual carbonate to react with sodium to enhance the sodium hazard in the soil as discussed in [32] [33]. According to as discussed in [16] [17], RSC values $<1.25 \mathrm{meq} / \mathrm{L}$ are considered as safe for irrigation while those from $1.25 \mathrm{meq} / \mathrm{L}$ to $2.5 \mathrm{meq} / \mathrm{L}$ are marginally suitable for irrigation and RSC values $>2.5$ are indicative that the groundwater is unsuitable for irrigation. Continuous irrigation with waters having RSC greater than $2.5 \mathrm{meq} / \mathrm{L}$ results in salt development which impedes the movement of air and water by clogging the soil pores as discussed in [34] [35]. The RSC values of Abuja FCT groundwater fall between -9.8 to $0.55,94$ samples, $100 \%$ are $<1.25$ as seen in Figure 14 thus the groundwater is suitable for irrigation.

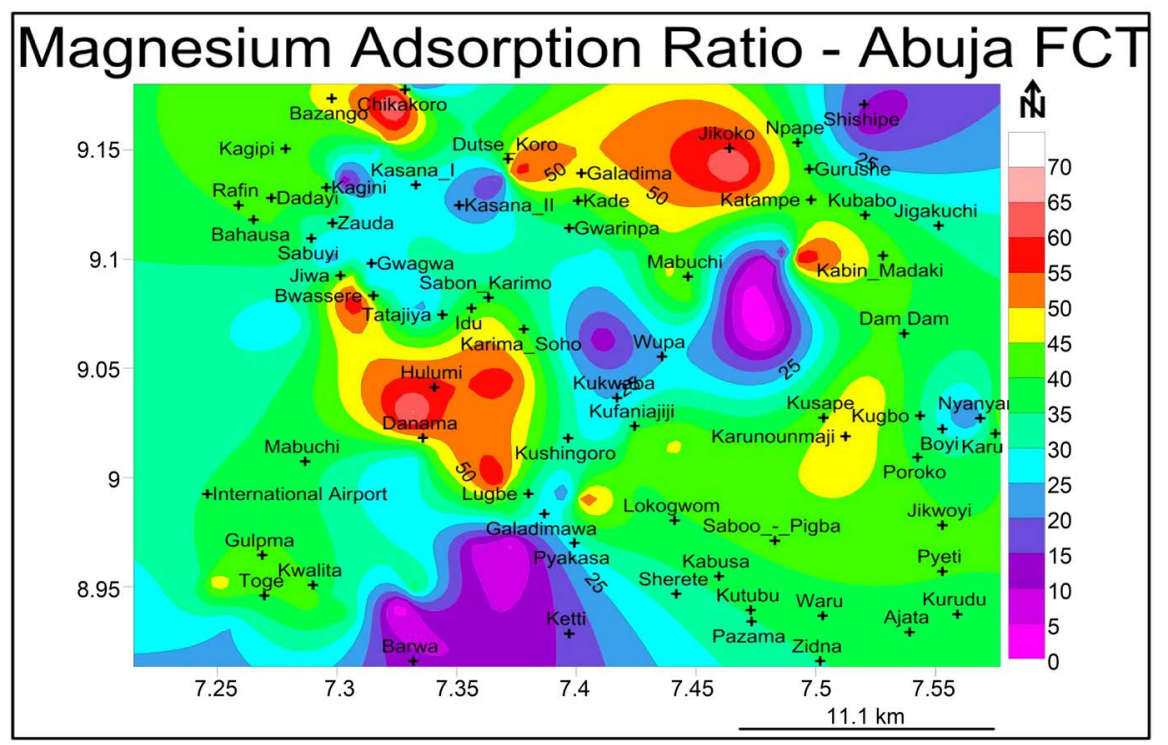

Figure 13. Spatial variation of magnesium adsorption ratio in the study area; Note increase in MAR values at Chikakoro, Jikoko, Hulumi, Danama, and Bwassere while MAR values are low at Barwa and Shishipe. 


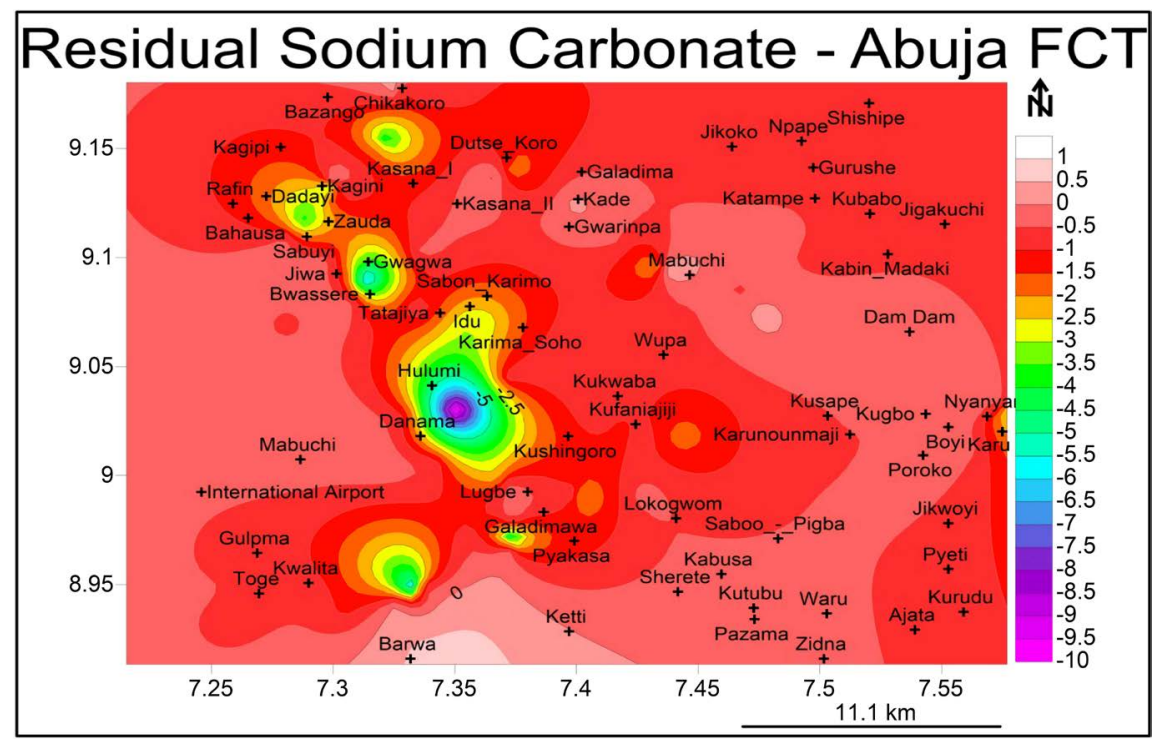

Figure 14. Spatial variation of residual sodium carbonate in the study area; Note increase in RSC values at Rafin, Mabuchi, Barwa, Dam Dam, Chikakoro, Jiwa, Kade, and Gwarinpa while low values are at Hulumi, Danama, Dadayi, Idu, and Tatajiya.

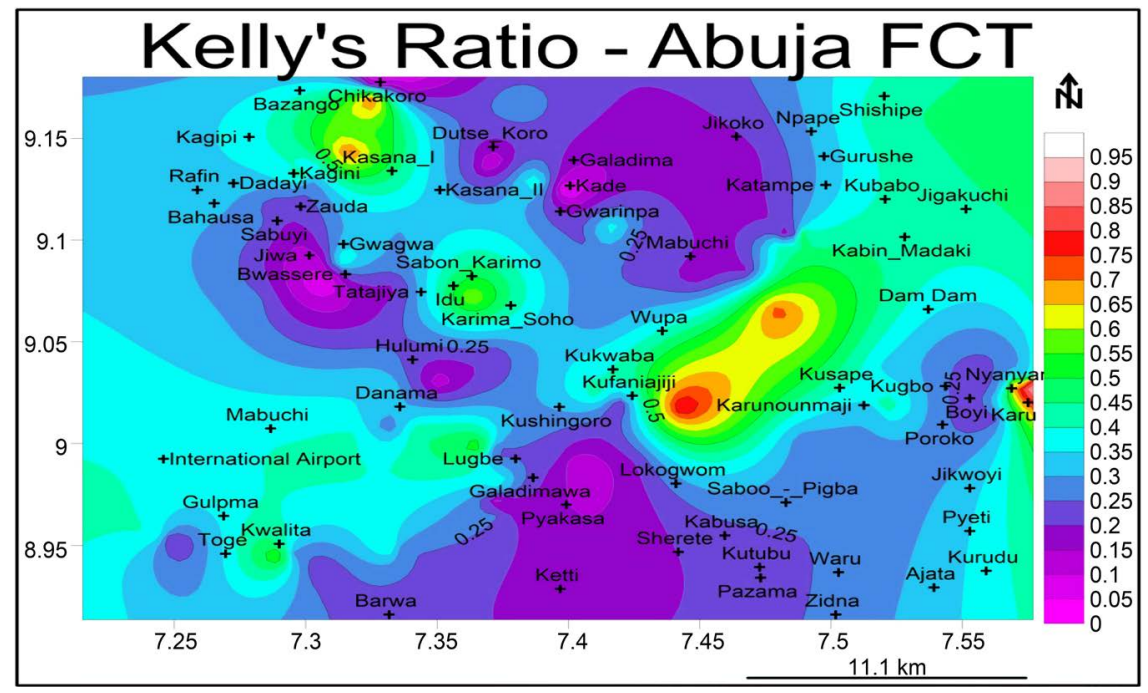

Figure 15. Spatial variation of Kelly's ratioin the study area; Note increase in KR values at Kuru, Nyanyan, and Kasana whereas low values are at Ketti, Sherete, Galadima, Pyakassa, Jiwa, Bwassere, and Jikoko.

\subsection{Kelly's Ratio}

Kelly's Ratio is computed by dividing sodium ion concentration versus calcium and magnesium ion concentrations as discussed in [14]. Water with KR value < 1 are regarded suitable for irrigation, while those with higher values are considered unsuitable. The KR of groundwater in Abuja FCT values vary between $0.01-0.68,94$ samples, $100 \%$ are $<1$ suitable for irrigation suitable for irrigation as seen in Figure 15. These KR values are similar to those of as discussed in [36] carried out in the groundwater of similar basement in Yaoundé Cameroon and in a sedimentary setting in Vadodara District, Gujarat, India where $33.3 \%$ of 
pre-monsoon groundwater samples had KR values were $<1$ as discussed in [37].

\section{Conclusions}

The groundwater of Abuja FCT has been evaluated for its water quality for Urban and Peri-Urban (UPA) Agricultural Irrigation.

The quality classifications of irrigation water based on the values: Sodium Adsorption Ratio SAR, Wilcox, Kelley Ratio KR, Residual Sodium Carbonate RSC, Permeability Index PI and Percent Sodium \%Na; indicate that groundwater of Abuja FCT is suitable for irrigation purpose on all soil types and that the groundwater will not degrade the soil.

However, United States Soil Salinity USSL Index of Abuja FCT groundwater fall in "very low to high salinity" and "low sodium hazard zone" and Magnesium Adsorption Ratio MAR indicates half of the groundwater as "not suitable".

Hence the groundwater in Abuja FCT should be used only on soils that are well drained.

\section{Conflicts of Interest}

The authors declare no conflicts of interest regarding the publication of this paper.

\section{References}

[1] FAO (1999) The State of Food and Agriculture 1999: Hunger Declining, But Unevenly. http://ftp.fao.org/docrep/fao/meeting/012/k1915e.pdf

[2] FAO (2008) Urbanization and Food Security in Sub Saharan Africa. Information Paper for the FAO 25th African Regional Conference.

[3] FAO (2004) Globalization of Food Systems in Developing Countries: Impact on Food Security and Nutrition. FAO, Rome, 97 p.

[4] FAO (2005) Farming in Urban Areas Can Boost Food Security. FAO Newsroom. http://www.cipotato.org/publications/pdf/003952.pdf

[5] UNDP (1996) Urban Agriculture: Food, Jobs and Sustainable Cities. United Nations Development Program, Publication Series for Habitat II, Volume One. UNDP, New York.

[6] Prain, G. (2007) Impacts of Urban Agriculture. Highlights of Urban Harvest Research and Development, 2003-2006. International Potato Center (CIP).

http://www.cipotato.org/urbanharvest

[7] Mc-Curry, P. (1985) The Geology of the Precambrian to Lower Paleozoic Rocks of Northern Nigeria. A Review. In: Kogbe, C.A., Ed., Geology of Nigeria, Elizabethan Co., Lagos, 15-39.

[8] Ajibade, A.C. and Wright, J.B. (1988) Structural Relationship in Schist Belts of Northwestern Nigeria. In: Oluyide, P.O., et al., Eds., Precambrian Geology of Nigeria, A Publication of Geological Survey, Ibadan, Nigeria, 103-109.

[9] Ajibade, A.C. (1976) Proterozoic Crustal Development in the Pan-African Regime of Nigeria. In: Kogbe, C.A., Ed., Geology of Nigeria, Rock View Ltd., Ibadan, Nigeria, 57-63.

[10] Ajibade, A.C. and Woakes, M. (1983) Proterozoic Crustal Development in the 
Pan-African Regime of Nigeria. In: Kogbe, C.A., Ed., Geology of Nigeria, Rock View Ltd., Ibadan, Nigeria, 57-63.

[11] WRC (1992) Groundwater Sampling Manual. Water Research Commission (WRC), Pretoria.

[12] American Public Health Association APHA (1985) Standard Methods for Examination of Water and Waste Water. American Public Health Association, American Water Works Association and Water Pollution Control Federation, Washington DC.

[13] Wilcox, L.V. (1995) Classification and Use of Irrigation Waters. USDA Circular No. 960, Washington DC, 19.

[14] Kelley, W.P. (1940) Permissible Composition and Concentration of Irrigation Waters. Proceedings of the American Society of Civil Engineers, 66, 607-613.

[15] Paliwal, K.V. (1972) Irrigation with Saline Water. Monogram No. 2 (New Series), IARI, New Delhi, 198.

[16] Eaton, E.M. (1950) Significance of Carbonate in Irrigation Water. Soil Science, 69, 123-133. https://doi.org/10.1097/00010694-195002000-00004

[17] Richards, L.A. (1954) Diagnosis and Improvement of Saline Alkali Soils: Agriculture. Vol. 160, Handbook 60, USDA, Washington DC.

[18] Doneen, L.D. (1962) The Influence of Crop and Soil on Percolating Water. Biennial Conference on Groundwater Recharge, 156-163.

[19] Kahlown, M.A, Tahir, M.A., Rashid, H. and Bhatti, K.P. (2006) Water Quality Status. Fourth Technical Report 2004-06, PCRWR, Islamabad.

[20] Jain, M.K., Dadhich, L.K. and Kalpana, S. (2011) Water Quality Assessment of Kishanpura Dam, Baran, Rajasthan, India. Nature Environment and Pollution Technology, 10, 405-408.

[21] Toumi, N., Hussein, B.H. and Rafrafi, S. (2015) Groundwater Quality and Hydrochemical Properties of Al-Ula Region, Saudi Arabia. Environmental Monitoring and Assessment, 187, 84. https://doi.org/10.1007/s10661-014-4241-4

[22] Ayers, R.S. and Westcott, D.W. (1985) Water Quality for Agriculture. Food and Agriculture Organization of the United Nations, Rome.

[23] Karanth, K.R. (1987) Ground Water Assessment: Development and Management. Tata McGraw-Hill Education, New York.

[24] Hadian, M.S., Azy, F.N., Krismadiyanti, I., Arfani, D.L., Sofyan, E.T., et al. (2015) Groundwater Quality Assessment for Suitable Drinking and Agricultural Irrigation Using Physico-Chemical Water Analysis in the Rancaekek Jatinangor District, West Java, Indonesia.

[25] As, B.G., Horneck, D.A., Stevens, R.G., Ellsworth, J.W. and Sullivan, D.M. (2007) Managing Irrigation Water Quality for Crop Production in the Pacific Northwest. A Pacific Northwest Extension Publication, 597.

[26] Smith, E., Porter, W., Hawkins, G. and Harris, J.G. (2016) Blueberry Irrigation Water Quality. UGA Cooperative Extension Bulletin, Circular 1105.

[27] JanardhanaRaju, N., Reddy, T.V.K., Kotaiah, B. and Nayudu, P.T. (1992) A Study on Seasonal Variations of Ground Water Quality in Upper Gunjanaeru River Basin, Cuddapah District, Andhra Pradesh. Fresenius Environmental Bulletin, 1, 98-103.

[28] Pandian, K. and Sankar, K. (2007) Hydrochemistry and Groundwater Quality in the Vaippar River Basin, Tamil Nadu. Journal of the Geological Society of India, 69, 970-982. 
[29] Reeve, R.C., Bower, C.A., Brooks, R.H. and Gschwend, F.B. (1954) A Comparison of the Effects of Exchangeable Sodium and Potassium upon the Physical Condition of Soils. Soil Science Society of America Journal, 18, 130. https://doi.org/10.2136/sssaj1954.03615995001800020004x

[30] Al-Tabbal, J.A. and Al-Zboon, K.K. (2012) Suitability Assessment of Groundwater for Irrigation and Drinking Purpose in the Northern Region of Jordan. Journal of Environmental Science and Technology, 5, 274-290.

https://doi.org/10.3923/jest.2012.274.290

[31] Tripathi, A.K., Mishra, U.K., Mishra, A., Tiwari, S. and Dubey, P. (2012) Studies of Hydrogeochemical in Groundwater Quality around Chakghat Area, Rewa District, Madhya Pradesh, India. International Journal of Modern Engineering Research, 2, 4051-4059. http://www.ijmer.com

[32] Strawn, D.G., Bohn, H.L. and O’Conner, G.A. (2015) Soil Chemistry. 4th Edition, John Wiley and Sons Ltd., West Sussex, 342.

[33] Almeida, C., Quintar, S., González, P. and Mallea, M. (2008) Assessment of Irrigation Water Quality. A Proposal of a Quality Profile. Environmental Monitoring and Assessment, 142, 149-152. https://doi.org/10.1007/s10661-007-9916-7

[34] Nishanthiny, S.C., Thushyanthy, M., Barathithasan, T. and Saravanan, S. (2010) Irrigation Water Quality Based on Hydro Chemical Analysis, Jaffna, Sri Lanka. American-Eurasian Journal of Agricultural \& Environmental Sciences, 7, 100-102.

[35] Naseem, S., Hamza, S. and Bashir, E. (2010) Groundwater Geochemistry of Winder Agricultural Farms, Balochistan, Pakistan and Assessment for Irrigation Water Quality. European Water, 31, 21-32.

[36] Akoachere, R.A. II, Yaya, O.O., Egbe, S.E., Eyong, T.A., Nji, B.N. and Tambe, D.B. (2019) GIS-Hydrogeo-Chemical Model of the Yaoundé Fractured Rock Aquifer, Cameroon: Aquifer Setting, Seasonal Variations in Groundwater-Rock Interaction and Water Quality. Journal of Geoscience and Environment Protection, 7, 232-263. https://doi.org/10.4236/gep.2019.75018

[37] Bhat, M.A., Wani, A.S., Vijay, K., Jyotirmaya, S. and Dinesh, T. (2018) An Overview of the Assessment of Groundwater Quality for Irrigation. Journal of Agricultural Science and Food Research, 9, 209. 